$\Delta 19$

Treatment of neonatal neutropenia with recombinant humar granulocyte colony-stimulating factor (rhG-CSF)

Alison R Bedford Russell, E Graham Davies, Sarah E Ball., Edward C Gordon-Smith . Depts Child Health \& Haematology St George's Hospital Medical School, London SW17 ORE. Background: The outcome of neonatal septic neutropenia is

Methods Uncontrolled pilot study of rhG-CSF as adjuvant therapy in 12 neutropenic preterm infants (24-35 weeks gestation). All received appropriate antibiotics.

Results Median (range) values shown

\begin{tabular}{||l|l|l|c||}
\hline $\begin{array}{l}\text { Absolute } \\
\text { counts }\end{array}$ & $\begin{array}{l}\text { Pre- } \\
\text { treatment }\end{array}$ & $\begin{array}{l}\text { Peak post- } \\
\text { treatment }\end{array}$ & $p$ \\
\hline $\begin{array}{l}\text { Neutrophils } \\
\text { x10\%/L }\end{array}$ & $\begin{array}{l}0.7 \\
(0.1-1.2)\end{array}$ & $\begin{array}{l}6.6 \\
(0.8-61)\end{array}$ & $<0.01$ \\
\hline $\begin{array}{l}\text { Platelets } \\
\text { x10\% } / L\end{array}$ & $\begin{array}{l}136 \\
(34-235)\end{array}$ & $\begin{array}{l}39 \\
(19-103)\end{array}$ & $<0.05$ \\
\hline
\end{tabular}

six infants recovered from acute, severe illness (4 with ith probable sepsis). Four infants died from respiratory distress syndrome; 2 others were moribund pre-treatment and died after their first doses of rhG-CSF. Conclusions RhG-CSF may correct neutropenia; prophylacti use is likely to be of more benefit than interventiona use; thrombocytopenia may be a side effect.

\section{$\triangle 20$}

\section{DIFFICULTIES IN DIAGNOSIS OF SECONDARY LEUKEMIA IN Auke Beishuizen ${ }^{1}$, Elisabeth R. van Wering ${ }^{2}$, Karel Hählen ${ }^{2,3}{ }^{3}$. \\ 'Dept. of Immunology, University Hogpital//Erasmus University, Rotterdam;
${ }^{2}$ Dutch Childhood Leukemia Study Group, The Hague; Dept. of Pediatrics, Subdivision Hematology-Oncology,
Sophia Children's Hospital/Erasmus University, Rotterdam, The Netherlands.}

Despite major improvements in the treatment of acute lymphoblastic leukemia (ALL) patients during the last two decades, $20-30 \%$ of children with ALL still relapse. In 5-10\% of thes relapses a secondary leukemia is diagnosed. Most secondary leukemias are myeloid in origin and only $5-10 \%$ are lymphoid.

Fourty ALL patients were analyzed for their cytomorphology, immunophenotype and immunogenotype at diagnosis and relapse. Immunogenotypic studies included the analysis immunoglobulin heavy chain $(\operatorname{IgH})$, Ig $\alpha$, Ig $\lambda$, T-cell receptor $-\beta$ (TCR- $\beta$ ), TcR- $\gamma$, and TcR- $\delta$ genes. In two precursor B-ALL cases an interlineage shift to acute myeloid leukemia (AML) occurred. suggesting the development of a secondary leukemia. In one of them, a complete change in immunogenotype at relapse was found, supporting the diagnosis of secondary leukemia. However, in the other case, seven identically rearranged IgH and TCR alleles were still present at relapse, indicaling that the AML was related to the precursor B.ALL at diagnosis and thereby excluding the development of a secondary leukemia. In a third precursor B-ALL, the immunophenotype at diagnosis and relapse was identical, but a completely different immunogenotype (on at least ten $\mathrm{lg}$ and TCR alleles) was found at relapse, suggesting secondary ALL. Unfortunately, no cytogenetic data at diagnosis and relapse were available for

These three cases demonstrate the difficulties in defining a secondary leukemia based on cytomorphology and immunophenotype and emphasize the importance of immunogenetic studies as well as cytogenetic analysis of malignant cell samples to determine the clonal relation or clonal evolution between diagnosis and relapse.

\section{1}

ARE THERE CHANGES IN CARDIO-PULMONARY HEMODYNAMICS AFTER A THERAPEUTIC DOSE OF INDOMETHACIN? Manon J.N.L. Benders, Margot van A THERAPEUTIC DOSE OF INDOMETHACIN? Manon J.N.L. Benders,
de Bor, Frank van Bel. Dept of Pediatr, Univ Hosp Leiden, The Netherlands.

Previous studies showed an early increase in systemic vascular resistance and a decrease in the perfusion of brain, kidneys and intestines for at least $2 \mathrm{~h}$. The effect of Indo on cardiopulmonary hemodynamics was studied in 14 preterm infants. PDA was diagnosed clinically and confirmed by echocardiography. We measured LV-output $\left(\mathrm{mL} / \mathrm{mL} . \mathrm{min}^{-1} \mathrm{~kg}^{-1}\right)$ and the resistance in the ascending aorta (RAO; $\mathrm{mmHg} / \mathrm{mL} \cdot \min ^{-1} \mathrm{~kg}^{-1}$ ) before Indo and during the first $12 \mathrm{~h}$ after a single i.v. dose $0.1 \mathrm{mg} / \mathrm{kg}$ at $1 \mathrm{~h}, 4 \mathrm{~h}$ and $12 \mathrm{~h}$. To assess changes in ductal patency and postductal pulmonary flow we measured peak velocities at the ductal. pulmonary opening (D-PV) and in the left pulmonary artery (P-PV) in m.sec.-1. Results: All 14 infants had clinical signs of PDA at $1 \mathrm{~h}$ after Indo, this number was reduced to 9 at $4 \mathrm{~h}$ 14 infants had clinical signs of PDA at $1 \mathrm{~h}$ after Indo, this number was reduced to 9 at $4 \mathrm{~h}$
after Indo but in only 1 infant ductus closure was definite. Measurements are summarized \begin{tabular}{lcccc} 
in the table: & Pre-Indo & $1 \mathrm{H}$ after & $4 \mathrm{H}$ after & $12 \mathrm{H}$ after \\
\hline LV output & $386 \pm 54$ & $248 \pm 38^{*}$ & $250 \pm 36$ & $275 \pm 34$
\end{tabular}

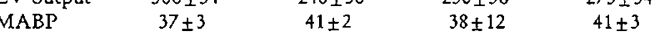

$\begin{array}{lllll}\text { RAO } & 0.11 \pm 0.01 & 0.21 \pm 0.02^{*} & 0.16 \pm 0.02 & 0.16 \pm-0.16\end{array}$

$\begin{array}{lllll}\text { D.PV } & 1.33 \pm 0.09 & 1.52 \pm 0.11 & 0.84 \pm 0.15 \mathrm{H} & 0.99 \pm 0.12 \mathrm{H}\end{array}$

\begin{tabular}{|c|c|}
\hline & $0.87+0.04 \quad 0.86+0.07$ \\
\hline
\end{tabular}

Conclusions: At $1 \mathrm{~h}$ after, $0.1 \mathrm{mg}$ Indo caused constriction of the systemic vascular bed with a concomitant decrease in LV-output. Ductal patency and pulmonary vascular with a concomitant decrease in $L$-output. Ductal patency and pulmonary vascular effect on the ductus, whereas its systemic vascoconstrictive effect subsided.

\section{2}

HEMODYNAMIC CONSEQUENCES OF PHOTOTHERAPY (PT) IN PRETERM INFANTS. Manon N.J.L. Benders, Frank van Bel, Margot van de Bor. Dept. of Pediatrics, Univ. Hosp. Leiden, The Netherlands.

Hemodynamic effects were determined in 18 preterm infants undergoing blue-light PT for hyperbilirubinemia using $2 \mathrm{D} /$ pulsed Doppler ultrasound. Mean \pm SD birth weight and gestational age were $1475 \pm 757 \mathrm{~g}$ and $30.0 \pm 4.5$ wks respectively. The mean age at which PT was initiated was $4.4 \pm 3.7$ days. Left ventricular output (LVO), blood flow velocities in the left pulmonary artery (PBFV), right internal carotid artery (CBFV), and the right renal artery (RBFV) were studied in all infants just prior to the onset of PT, $1 / 2 \mathrm{~h}, 2 \mathrm{~h}, 12 \mathrm{~h}$ after initiation of PT and before and $12-24 \mathrm{~h}$ after discontinuation of PT. Patency of the ductus arteriosus (PDA) was assessed at all ultrasound examinations. Mean CBFV increased significantly $(15.3 \% ; p<0.05)$ and mean RBFV decreased significantly $(19.2 \% ; \mathrm{p}<0.05)$ during the first $12 \mathrm{~h}$ of $\mathrm{PT}$. After discontinuation of $\mathrm{PT}$, $\mathrm{CBFV}$ as well as RBFV values returned to baseline values. LVO and mean PBFV increased significantly $\geq 12$ h of PT: $26.3 \% ; \mathrm{p}<0.05$ and $22.6 \% ; \mathrm{p}<0.01$ respectively. LVO as well as mean PBFV remained at higher levels after the withdrawal of PT than they had been before the onset of PT. It appeared that 9 of the 18 infants developed the infants without PDA had.

Conclusion: PT in preterm infants increased left cardiac output, PBFV and CBFV and decreased RBFV. The changes in CBFV and RBFV were however not associated with simultaneous changes in left cardiac output and PBFV. Furthermore, PT appeared to affect the patency of the ductus arteriosus, which resulted in a higher PBFV. This effect was more pronounced if PT lasted $>12 \mathrm{~h}$

PROSPECTIVE RANDOMIZED MULTICENTER TRIAL COMPARING SYNCHRONIZED AND CONVENTIONAL INTERMITTENT MANDATORY VENTILATION (SIMV vS IMV) IN NEONATES. Graham Bernstein, Frank L Mannino, Gregory P Hekdt, Dale H Bull, Augusto

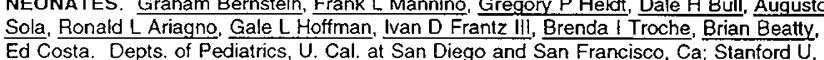
Palo Alto, Ca; NEMC, Boston, MA; Kosair CH, Louisville, KY; CHHC-San Diego, Ca, USA. At 6 centers, 306 infants with significant lung disease were randomized at $7.5 \pm 6 \mathrm{hrs}$ of At 6 centers, 306 infants with significant lung disease were randomized at $7.5 \pm 6 \mathrm{hrs}$.
age to SIMV or IMV. SIMV was performed with the InfantStar ventilator and Star Sync age to SIMV or IMV. SIMV was performed with the InfantStar ventilator and Star Sync
module. Infants on each mode had similar BW, GA, Apgar scores, arterial-alveolar oxygen module. Infants on each mode had similar BW, GA, Apgar scores, arterial-alveolar oxygen
(a/A) ratio at time of randomization, \# surfactant doses and rates of sepsis and PDA. The rates of mortality. IVH and pharmacologic paralysis were similar. The median duration ( $95 \%$ confidence interval) of mechanical ventilation of survivors was:

\begin{tabular}{|c|c|c|c|c|c|}
\hline \multicolumn{2}{|c|}{$B W<1 \mathrm{~kg}(n=73)$} & \multicolumn{2}{|c|}{$B W 1.2 \mathrm{~kg}(n=120)$} & \multicolumn{2}{|c|}{$B W>2 \mathrm{~kg}(\mathrm{n}=93)$} \\
\hline SIMV & IMV & $\underline{\text { SIMV }}$ & IMV & SIMV & IMV \\
\hline $\begin{array}{c}874 \mathrm{hr} \\
(359-1098)\end{array}$ & $\begin{array}{c}929 \mathrm{hr} \\
(596-1090)\end{array}$ & $\begin{array}{c}107 \mathrm{hr} \\
(98-171)\end{array}$ & $\begin{array}{c}122 \mathrm{hr} \\
(91-167)\end{array}$ & $\begin{array}{c}72 \mathrm{hr} * \\
(64-78)\end{array}$ & $\begin{array}{c}96 \mathrm{hr} \\
(73-106)\end{array}$ \\
\hline
\end{tabular}

In infants with $\mathrm{BW}<1 \mathrm{~kg}$, the need for supplemental $\mathrm{O}_{2}$ at 35 weeks corrected age was less for SIMV $(46 \%)$ than IMV $(77 \%)$, p $<0.05$. In infants with BW $1-2 \mathrm{~kg}$ there was more rapid improvement on SIMV with lower average $\mathrm{FiO}_{2}$ and higher a/A ratio during the first 12 hours $(p<0.05)$. and a trend for less sedation with benzodiazepines $(p=0.08)$ and morphine $(p=0.1)$ during the first 10 days. In infants with $B W>2 \mathrm{~kg}$, there were trends toward decreased pneumothorax occurrence and need for ECMO on SIMV (both $p=0.1$ ). SIMV compared to IMV in sick newborns can improve oxygenation, shorten the duration of ventilation and reduce chronic lung disease. (Funded in part by Infrasonics, Inc.) 